\title{
EVIDENCE IN INTERNATIONAL COMMERCIAL ARBITRATION
}

\author{
Michal Malacka ${ }^{1}$ \\ Faculty of Law, Palacký University Olomouc, Czech Republic \\ email: michal.malacka@upol.cz
}

MALACKA, Michal. Evidence in International Commercial Arbitration. International and Comparative Law Review, 2013, Vol. 13., No. 1, pp. 97-104. DOI: 10.1515/iclr-2016-0061.

\begin{abstract}
International commercial arbitration and national commercial arbitration are issues of international private law combined with global and local aspects. The rules of the procedure in international commercial arbitration vary around the world and are combined with the very strong influence of national law and are determinate by the place where the arbitration procedure is being preceded by the arbitrators. Obtaining evidence in commercial arbitration is also dependent on the above-mentioned aspects. The arbitrators have to know, as much as possible, all about the common law system, the civil law system's influence and the powers and initiation possibilities they have during the arbitration procedure. The knowledge of the system and existing procedure rules allow them to produce the most important part of the arbitration, such as a perfect award.
\end{abstract}

Keywords: International commercial arbitration, obtaining of evidence, practice.

\section{International commercial arbitration and the process of evidence}

There is no doubt that the evidence is a very important part of international arbitration; regulation of taking evidence and proceeding evidence together with the discovery of evidence are essential parts not only of national arbitration also for international commercial arbitration ${ }^{2}$. Each arbitrator should have knowledge about the law governing the evidence, about rules depending on lex loci arbitrii ${ }^{3}$ and its background. This is very important on the practical platform, but also for the academic platform, where we have to count with students, teachers and law experts examining and researching the field of international commercial arbitration.

1 Michal Malacka is a Senior Lecturer at Department of Commercial Law and Private International Law, Faculty of Law, Palacký University in Olomouc, Czech Republic. Email: michal.malacka@ upol.cz.

2 Comp. Cooley, J.W., The Arbitrator's Handbook, Second Edition, NIFTA 2005, p. 92

3 Varady, T., Barceló, J.J., von Mehren, A.T., International Commercial Arbitration, Thomson/ West 2006, p.453, Bělohlavek, A.J., B2C: Consumer Protection in Arbitration, p.65

\footnotetext{
(c) Palacký University Olomouc, Czech Republic, 2013. ISSN 1213-8770 (print), ISSN: 2464-6601 (online).
} 
This article is an introduction into the problems of evidence on international arbitration and was prepared on the occasion of the Pre Moot conference for the Vis Moot of VIAC in Vienna ${ }^{4}$. Thanks to Moot training, we are able not only to focus on practical aspects but also on training law students on the procedure of taking evidence, combined with research, drafting and playing advocacy. This is not only promoting international commercial arbitration, it is also a great practical step for the study of international commercial arbitration. With the help of that practical methodology we are able to prepare future experts of dispute resolution and international commercial arbitration. The concept of the Moot is pretty near to the Praxis of international arbitration. Just like the arbitrators in commercial arbitration, the students too have to research the best arguments for the claimant and for respondent. They have to prepare their arguments in the form of memoranda and combine this with a knowledge of international trade law.

\section{International commercial arbitration and evidence}

All experts in the field of international commercial arbitration are aware that arbitration has developed as one of the most efficient methods of commercial dispute resolution. The importance of international commercial arbitration is growing, and in the field of commercial law with international aspects, international arbitration comparing national courts is the leading method of dispute resolution. ${ }^{5}$ We will put the analysis of the problem concerning alternative dispute resolution and all the methodology used in ADR aside. Neither will the discussion about the relationship between state courts and arbitration be the topic of this study. Evidence in international commercial arbitration has the same history as the arbitration itself. For most experts, it comes as a surprise that international arbitration is more preferred and better known in civil law systems. It is interesting when comparing the origin of ADR. ${ }^{6}$

International commercial arbitration becomes important in the common law system with the United States' ratification of the United Nations Convention on the Recognition and Enforcement of Foreign Arbitral Awards. Since its ratification in 1970, the number of countries participating coming from the common law system is growing. ${ }^{7}$ For the proceeding system of international commercial arbitration this moment was important because of the influence of common law on the rules of international arbitration and evidence in the process. Since the ratification of the United Nations Convention, specific aspects have been enter-

4 http://www.cisg.law.pace.edu/vis.html

5 Goldsmith, J.C., ADR in Business, Kluver law international, 2006, p. 8

6 Goldsmith, J.C., ADR in Business, Kluver law international, 2006, p. 7

7 Rhoades, R.V., Kolkey, D.M., Chernick, R., Practitioner's Handbook on International Arbitration and Mediation, JurisNet, LLC, 2007, p. 275 
ing into international arbitration. For example, pre-hearings and cross examination now have a stronger position in proceedings of international commercial arbitration. The influence of the common law system is also evident in the rules of evidence in arbitration proceedings. ${ }^{8}$

\section{Rules of evidence in arbitration proceedings and at institutional arbit- ration courts}

Rules of evidence are not the same in different countries due to the very nature of their legal systems. The definition of the rules of evidence in international commercial arbitration describes the aggregate of laws that govern the relevance and weight of documentary and oral evidence mentioned by a party, including the preparation and presentation of witnesses, experts, documents and local inspections and results of hearings in order to support a fact in an issue of the legal proceeding. ${ }^{9}$

For international commercial arbitration, it would probably be better to use the term rules. Not only because of the differences in all national law systems, but especially due to the many differences in various international commercial arbitration rules existing in arbitration courts all over the world. ${ }^{10}$ And here again arises the problem of the conflict between common law and civil law systems. The problem is combined when the parties come from different legal systems. The arbitrators are obliged to determine the relevance and weight of the evidence. The biggest difference comparing the common law system and the civil law system is in the relevance of written evidence preferred by civil law systems, and oral evidence combined with witness statements in common law systems. This problem is perhaps combined with tradition in civil procedures and proceedings by national courts. Using juries in similar proceedings and counting on the principle of justice in common law systems is bringing these traditional differences from national courts into the arbitration. ${ }^{11}$ The influence of the common law sister on international arbitration is bringing some differences, but there is a strong interest to have balance in the proceeding, especially in international arbitration. So arbitrators are using international rules for international commercial arbitration. We have to differentiate whether the international commercial arbitration ad hoc is in process, or an institutional commercial arbitration preceded by an international arbitration court. ${ }^{12}$ In the case of international arbitration

8 Rhoades, R.V., Kolkey, D.M., Chernick, R., Practitioner's Handbook on International Arbitration and Mediation, JurisNet, LLC, 2007, p. 165

9 Comp. Rhoades, R.V., Kolkey, D.M., Chernick, R., Practitioner's Handbook on International Arbitration and Mediation, JurisNet, LLC, 2007, p. 159 and . Cooley, J.W., The Arbitrator's Handbook, Second Edition, NIFTA 2005, p. 93

10 Lowenfeld, A.F., International Litigation and Arbitration, Thomson/West 2005, p.129-189

11 Rhoades, R.V., Kolkey, D.M., Chernick, R., Practitioner's Handbook on International Arbitration and Mediation, JurisNet, LLC, 2007, p. 165-183

12 Varady, T., Barceló, J.J., von Mehren, A.T., International Commercial Arbitration, Thomson/ West 2006, p. 21 
court, there are rules set up which the arbitrators can follow. ${ }^{13}$ In other cases, so-called ad hoc arbitrators are often using the IBA rules. The International Bar Association rules for taking evidence in commercial arbitration - "IBA rules" are a good example of internationally prepared rules by a group of experts for international arbitration - especially international commercial arbitration. The rules are prepared to fulfill the expectation of practitioners coming from common law and civil law systems. The rules are related to the rules of evidence and represent a compromise in the practice of evidence. The rules in their construction allow a party to request the opposite party to produce some documents in a restricted number. This is very important in relation to the costs of the case, and also for setting and specifying the category of documents and identification of the document's importance. ${ }^{14}$

Following the rules of most international arbitration institutions, we can find a limited number of typical evidence procedures. Typical international arbitration institutions are the International Court of Arbitration of the International Chamber of Commerce - the ICC $^{15}$ - or the rules of the London Court of International Arbitration - LCIA ${ }^{16}$ - and the rules of the American Arbitration Association - $\mathrm{AAA}^{17}$.

Much more detailed than the majority of institutional arbitration rules are the above-mentioned IBA rules. IBA rules describe five basic kinds of evidence in international arbitration. The first position is covered by documentary evidence in Article 3. Article 4 describes witness evidence and Articles 5 and 6 cover expert evidence - appointed by one of the parties or by the arbitrators. Article 8 describes on-site inspection and the five most important parts of evidence following IBA rules, which is the admissibility and assessment of evidence. ${ }^{18}$

National arbitration and also international arbitration allow the arbitrators not to adopt the rules as such, but to use them as guidelines. Thanks to nonformal aspects of international arbitration, it is possible for the arbitrators to use freedom in the taking of evidence and the flexibility of the proceedings. This aspect, is combined with IBA rules that follow international arbitration practice. They also reflect different legal traditions, the above-mentioned civil law and common law systems. Analyzing evidence in the written and oral phase, the written part is closer to the serial law system and leaves more room for production of documents. The oral part is closer to the common law tradition even if it is divided into parts - in a written part, in the form of written witness statement, followed by an oral examination during the hearing. ${ }^{19}$ This is combined with

13 Lowenfeld, A.F., International Litigation and Arbitration, Thomson/West 2005, p. 129

$14 \mathrm{http}: / /$ www.ibanet.org/Publications/publications_IBA_guides_and_free_materials.aspx

15 Lowenfeld, A.F., International Litigation and Arbitration, Thomson/West 2005, p. 165

16 Lowenfeld, A.F., International Litigation and Arbitration, Thomson/West 2005, p. 189

17 Lowenfeld, A.F., International Litigation and Arbitration, Thomson/West 2005, p. 129

18 http://www.ibanet.org/Publications/publications_IBA_guides_and_free_materials.aspx

19 Rhoades, R.V., Kolkey, D.M., Chernick, R., Practitioner's Handbook on International Arbitration 
cross examination of the opposite side by the arbitrators. Are there some questions arising with this procedure? The most important question is how arbitrators assess the probative value of evidence. Simply and practically described, we have to ask if some evidence has more power or weight than others. ${ }^{20}$ Following both of the above-mentioned systems, civil and common law, there is no perfect answer to all possible questions. It depends on the budget allotted to each case and on the quality and style in which the parties have presented the case. It is also very hard to find the right answer for the question of regulation in the burden of proof situation. Burden of proof is regulated only in some institutional arbitration rules and the arbitrators are often taking inspiration from the AAA and the United Nations Commission on International Trade $\mathrm{Law}^{21}$.

\section{Categories of evidence in international arbitration}

\subsection{Documentary evidence}

Documentary evidence includes the exhibits produced by the parties of the arbitration combined with their submissions prepared for hearings. Documentary evidence could be in the possession of both parties could be also be ordered to be produced. Arbitrators in international commercial arbitration are often ordering production of documents that are in the possession of parties. Following the common law system, regarding what each party believes are the relevant documents, it is an obligation for a party to produce every single relevant document in its position to the court. This phase of evidence procedure is executed after the submissions of the parties, and before the exchange of witness statements and the hearing. ${ }^{22}$

It is clear that documents are the means of evidence in arbitration. In an ideal case the position of the parties is clearly confirmed by the documents, but few cases are ideal and the documentary evidence does not always lead to a complete and final result. In practice, arbitrators have a few relevant documents on which they can rely. There are often problems with the written form of the documents. They are sometimes not clear, often in cases when the author of the document tried to express himself or herself in a foreign language. Not only the knowledge of foreign languages causes problems. Some documents are irrelevant but produced in multitudes. From the position of arbitrators, this, combined with the procedure, add up to the very high cost of international arbitration. ${ }^{23}$

and Mediation, JurisNet, LLC, 2007, p. 155 - 160

20 Cooley, J.W., The Arbitrator's Handbook, Second Edition, NIFTA 2005, p. 124

21 Lowenfeld, A.F., International Litigation and Arbitration, Thomson/West 2005, p. 211, 285

22 Rhoades, R.V., Kolkey, D.M., Chernick, R., Practitioner's Handbook on International Arbitration and Mediation, JurisNet, LLC, 2007, p. 165-170

23 Varady, T., Barceló, J.J., von Mehren, A.T., International Commercial Arbitration, Thomson/ West 2006, p. 316 


\subsection{Witness testimony}

International commercial arbitration understands a witness as any person, including a party representative or employee, whom can be heard. ${ }^{24}$ This is a flexible rule and it enables the arbitrators to hear any person with relevant testimony. In the modern procedure of international arbitration, the arbitrators have to take into account the costs of the procedure. So they have established the common practice of asking the parties to submit written witness statements, describing the knowledge of witnesses and their understanding of the relevant circumstances. In the final procedural aspects the subsequent hearing with cross examination and the questions of the arbitrators is very important. ${ }^{25}$

Similar as in the situation of documents evidence, witness testimonies are partly written for efficiency and cost reasons. Often witnesses do not write the witness statements on their own. Papers are prepared by the counsel or by the party. And this may have an impact on the content of the statement. Oral examination is important for the procedure and also for the arbitrators, because it is testing the credibility of the witness's written testimony.

The arbitrators are very often confronted with orally unconfirmed assessments of written testimony. ${ }^{26}$

\subsection{Expert evidence}

Expert evidence has an important position in international commercial arbitration. The expert statement is also one of the alternative dispute resolution methods, and the points of view of an expert are often used in international commercial arbitration as a kind of evidence. Expert evidence is related to technical, legal, financial or other expert issues and not only arbitrators have the power to appoint an expert - this possibility also pertains to the parties. ${ }^{27}$ It is also possible to appoint not only one expert - two or more experts can be appointed. This possibility is combined with the danger of the high costs of the procedure and arbitrators take care about the relevance of the expert evidence because the arbitrators have to be experts in and of themselves. ${ }^{28}$ The situation in the way of appointing experts is complicated because of missing rules in international commercial arbitration, but in the practice the appointment of an expert follows the use of both appointment methods. An agreement between arbitrators of both parties is a good practice because of the will of both parties to appoint their own arbitrator. Also the parties should carefully choose the problems for

24 Lowenfeld, A.F., International Litigation and Arbitration, Thomson/West 2005, p. 189

25 Cooley, J.W., The Arbitrator's Handbook, Second Edition, NIFTA 2005, p. 92-95

26 Cooley, J.W., The Arbitrator's Handbook, Second Edition, NIFTA 2005, p. 150

27 Cooley, J.W., The Arbitrator's Handbook, Second Edition, NIFTA 2005, p. 114

28 Cooley, J.W., The Arbitrator's Handbook, Second Edition, NIFTA 2005, p. 24, Varady, T., Barceló, J.J., von Mehren, A.T., International Commercial Arbitration, Thomson/West 2006, p. 265 
which expert evidence is necessary and where it can strength or weaken their statements. ${ }^{29}$

Arbitrators are not bound by experts' conclusions and it is not important whether the expert was appointed by the arbitration tribunal or by the parties. In some cases the experts produce contradictory opinions and the arbitrators have to decide which opinion is more credible. In this situation oral explanations are a help to the arbitrators. Also the position of an expert and his statement in the case could be a problem. Experts are not allowed to act as an adviser or in a position similar to the position of an arbitrator. Experts cannot decide the cases, they only deliver opinions. ${ }^{30}$

\subsection{On-site inspection}

International commercial arbitration uses on-site inspection as evidence. This is an inspection of the object of the dispute in the form of an inspection of the works, machinery, and/or relevant documents. ${ }^{31}$ The arbitrators must carefully analyze whether an inspection of the machinery is necessary and if the machines or components or another object have not changed since the start of the dispute. In cases concerning with some installations it could be useful for the arbitrators to inspect the installation to get a better understanding and more complex view. Both parties of the international commercial arbitration should be present during the inspection, and the arbitrators have to organize the procedure of statements, explanations and documentation in the form of pictures and recordings. ${ }^{32}$

\section{The importance of the evidence}

The arbitrators in the procedure of international commercial arbitration are trying to obtain all possible evidence to find and prove the material facts. The arbitrators play an active role in the exploration of the evidence and testimony and they have to search for the material facts of the case to arrive at an impartial award. Evidence in international arbitration helps to assess each party's argument and the arbitrators must mind balance and principles of fairness in the process of evidence.

The arbitrators should not only use their power to take and assess the evidence, they should also protect the rights of the parties and proceed carefully for a fair award. Different means of evidence have been mentioned, but it is hard to

29 Varady, T., Barceló, J.J., von Mehren, A.T., International Commercial Arbitration, Thomson/ West 2006, p. 504

30 Varady, T., Barceló, J.J., von Mehren, A.T., International Commercial Arbitration, Thomson/ West 2006, p.519

31 http://www.wipo.int/amc/en/arbitration/rules/index.html

32 Varady, T., Barceló, J.J., von Mehren, A.T., International Commercial Arbitration, Thomson/ West 2006, p. 568 
decide what kind of evidence is more important. It depends on the case and the variability of the arbitration. Arbitrators have to carefully analyze the different means of evidence which are submitted to them and choose carefully the rules, whether they come from international arbitration courts or institutionsor from the International Bar Association.

\section{Conclusion}

The importance of international commercial arbitration is growing also in Europe, and especially in the field of dispute resolution concerning commercial law with international aspects. International arbitration is, comparing the length of the procedure at national courts, the leading method of dispute resolution. Since the ratification of the United Nations Convention, new specific aspects have been entering into international arbitration. We have to differentiate whether the international commercial arbitration ad hoc is in process, or an institutional commercial arbitration proceeded by an international arbitration court. The International Bar Association rules for taking evidence in commercial arbitration - "IBA rules" - are a good example of internationally prepared rules, however the arbitrators will have the final say in evidentiary procedures, although the new IBA Rules provide a number of helpful clarifications and innovations for the process of taking evidence. There is also a risk combined with such detailed rules as the IBA Rules, using them - flexibility, as the main advantage of arbitration, could be lost in some situations. The underlying importance of gathering of all possible evidence is to find and prove the material fact and we have to keep in mind, that each arbitrator should have knowledge about the law governing the evidence, about rules depending on lex loci arbitrii. 